\title{
Development of Pediatric Pulmonology in the United Kingdom, Europe, and Australasia
}

\author{
SIMON GODFREY, KAI-HAKON CARLSEN, AND LOUIS I. LANDAU \\ Institute of Pulmonology [S.G.], Department of Pediatrics, Hadassah University Hospital, Jerusalem, \\ Israel; Department of Paediatric Allergology and Respiratory Medicine [K.-H.C.], University in Oslo, \\ Voksentoppen BKL, National Hospital, Oslo, Norway; and Faculty of Medicine and Dentistry [L.I.L.], \\ Department of Paediatrics, The University of Western Australia, Perth, Australia
}

\begin{abstract}
ABSTR
The organization of medicine in Europe, the UK and the
Commonwealth countries was always much less formal than in
the USA for many years and pediatricians interested in pediatric
lung disease and asthma often started off as adult internists or
specialists in adult pulmonary medicine. The early leaders in
developing a special interest in the breathing of children during
the 1940s and 1950s were predominantly physiologists and
clinicians who began to apply physiological techniques to the
study lung function in healthy and sick infants and children. A
major contribution to our understanding of the epidemiology of
wheezing in children was the early establishment of a cohort
study in Australia which is still yielding important information.
It was during the early 1970 s that pediatric pulmonary "politics"
began to emerge in the UK when pediatricians interested in lung
diseases began to arrange an informal society and meet regularly
under the auspices of the British Paediatric Association. In fairly
\end{abstract}
characteristic fashion, pulmonology in Europe was represented for a while by several different societies but due to the efforts of some dedicated enthusiasts there finally emerged the Paediatric Assembly of the European Respiratory Society (ERS) and its first Head, Max Zach, went to become President of the ERS itself. Despite some early doubts abut the future for pediatric pulmonology as a specialty in Europe and Australasia it is clearly flourishing as shown by the rising membership of the professional societies and the constant stream of high quality basic science and clinical publications. (Pediatr Res 55: 521-527, 2004)

\section{Abbreviations}

BPA, British Pediatric Association

EPRS, European Pediatric Respiratory Society

ERS, European Respiratory Society

LRPC, Long-Range Planning Committee
In many ways, the organization of medicine in Europe, the United Kingdom, and the commonwealth countries has always been much less formal than in the United States, especially in relation to specialty practice. Although some might regard this state of affairs as harmful to the practice of specialist medicine, it did allow for the relative ease with which physicians in training could move between subspecialties. This was especially true for pediatricians who were interested in pediatric lung disease and asthma, many of whom started as adult internists or specialists in adult pulmonary medicine. In this way, it was possible for the application of techniques borrowed from adult medicine, such as the measurement of lung function and bronchoscopy, to be introduced into pediatric practice with appropriate modifications. In Australia and New Zealand, pediatric pulmonology evolved, in some ways, as a hub between disciplines and between continents, very likely as a result of geographic isolation. There has been considerable movement

Received April 6, 2003; accepted August 7, 2003.

Correspondence: Simon Godfrey, M.D., Institute of Pulmonology, Hadassah University Hospital, POB 12000, Jerusalem 91120, Israel; e-mail: sgodfrey@netvision.net.il

DOI: 10.1203/01.PDR.0000112037.28065.F8 of those training in pediatric pulmonology between Australia, Europe, and North America. Collaborative studies with neonatologists, radiologists, immunologists, intensivists, and thoracic surgeons have led to valuable reports on the physiologic and clinical features of neonatal lung disease with analysis of long-term sequelae. The collaborations have enabled documentation, through epidemiologic studies, of the wide range of features associated with childhood lung diseases. In Europe and Australasia, the specialty of pediatric pulmonology evolved mainly over the second half of the 20th century, slowly at first but with increasing professionalism and organization as time went by. The development of subspecialization in pediatrics needs to be seen in light of the fact that it was only some $30 \mathrm{y}$ ago that pediatrics itself was recognized as distinct from internal medicine as far as the specialty examinations of the Royal Colleges of Physicians (board equivalents) were concerned.

It is interesting to speculate what drove academically minded pediatricians to specialize in pulmonology. Was it the advances in technology that enabled those with a physiologic bent to study lung function in children? Was it the ability to 
diagnose and treat cystic fibrosis? Or was it the awareness of the rapid increase in the incidence of asthma? Remember, the flexible fiber-optic bronchoscope and computed tomographic scanning came much later. Some may think that it was the development of safe and effective drugs for treating asthma with the large-scale funding available from the drug companies to finance research that provided the impetus, given that asthma and wheezing are such common problems in children.

\section{THE 1930s-1940s}

Where did it all start? Pediatricians and other physicians who treated children in the United Kingdom and elsewhere were chiefly involved in the management of infectious diseases, especially tuberculosis, until well into the 20th century. Apart from anecdotal reports of various lung diseases in children, it was only in approximately the 1930s that attention was focused in any scientific manner on the physiology and diseases of breathing in children-the forerunner of pediatric pulmonology. The fifth volume of the Archives of Diseases in Childhood, published in 1930, carries a wonderful account of asthma in children by Bray (1) with clinical and epidemiologic data, much of which could have been written today. Of children attending a special asthma clinic at the Hospital for Sick Children, London, $22 \%$ began to wheeze under $1 \mathrm{y}$ of age and $40.5 \%$ under $2 \mathrm{y}$-pretty close to what we know now from epidemiologic studies especially in Australia. However, there was almost nothing in this paper about the treatment of asthma other than the advice that "intermarriage between asthmatics should be discouraged."

Nothing really important developed in the field of pediatric pulmonology during the war years and immediate post-war period. On the whole, children were treated for lung problems by general pediatricians, and the pediatric journals carried only sporadic reports of pulmonary interest. Nevertheless, in the 1940 issue of the Archives of Disease in Childhood, there is an excellent account by Asherson (2) of the importance of bronchoscopy in the recognition and removal of nonopaque foreign bodies in children. Ten years later, there was still only a general interest in lung disease, and it is a chilling reminder to us today that in 1950 there was a 37\% mortality from pneumonia in children younger than $6 \mathrm{mo}$, despite the use of sulfonamides or penicillin (3).

\section{THE 1950s-1960s: THE "FOUNDING FATHERS" EMERGE}

A more specific interest in pediatric pulmonology started in the late 1940s and early 1950s, largely because of the increasing interest in the physiology of breathing in infants and children. One of the driving forces at this time was Kenneth Cross, who began studying the mechanics of breathing and chemical and control in the newborn infant using a "head out" plethysmograph that he developed (4-6). This was a wondrous device in which the infant was enclosed within a rigid box and its face peeped out through a soft inflatable "tire" that formed the seal. As long as the infant did not wriggle too much, respiration could be recorded from changes in pressure of the chamber. Across the world in Australia, Kate Campbell, a pediatrician interested in neonatology, made an outstanding contribution by noting objectively that it was oxygen that was responsible for causing retrolental fibroplasias in the premature infant (7). This she did by the simple expediency of noting a much lower incidence of retrolental fibroplasia in infants from a private nursery, where parents had to pay for the oxygen, as compared with the public nursery, where it was free and hence used much more liberally. In London, Leonard Strang was applying the then new technique of spirometry to normal children and reporting normal values of lung function for children aged between 7 and 18 y (8). In the late 1950s and early 1960s, Cross and others continued to expand the knowledge of neonatal and pediatric pulmonary physiology (9) while Strang was conducting a therapeutic trial in children with asthma using lung function as an outcome measure (10). In 1962, Dick Jones, a pediatrician at the Alder Hey Children's Hospital in Liverpool, reported a then totally novel observation that changed thinking about asthma forever (11). He showed that exercise lasting 8-12 min produced a fall in forced expiratory volume in $1 \mathrm{~s}$, which reached a minimum 1-5 min after exercise and then rapidly rose toward the resting level. The level of exercise determined the degree to which these changes were evoked. He also noted that the fall in forced expiratory volume in $1 \mathrm{~s}$ could be minimized or abolished by the inhalation of isoprenaline (isoproterenol). This was apparently the first demonstration of bronchial hyperreactivity in asthma using objective measurement to document the changes, although exercise-induced asthma had clearly been described almost 300 y earlier by Sir John Floyer (12). Jones and his colleagues went on to conduct a series of studies related to asthma severity and bronchial reactivity in children, and, in fact, using very simple techniques, they established many of the facts as we know them today about exercise-induced asthma $(13,14)$. Across the channel in continental Europe, pediatric pulmonology was also on the move with important clinical studies, especially of tuberculosis in children, by Jan Rudnik in Poland and Alf Backman in Finland while Alois Zapletal from then Czechoslovakia published his monumental work on lung function and forced expiratory flows in children (15), which is as valid and useful today as it was in 1969.

Toward the end of the 1950s, Howard Williams was appointed the first full-time director of research at the Royal Children's Hospital research foundation in Melbourne. He not only contributed to knowledge in pediatric pulmonology directly but also led the way as a mentor for the next generation of physicians in this specialty. His own reports included accurate descriptions of the clinical presentations and natural history of tuberculosis in childhood, analysis of the effects of the aspiration of milk on the lungs, and documentation of structural abnormalities of the airways leading to bronchomalacia (16). He was a pioneer of physician endoscopy, although at the time, this was restricted to rigid bronchoscopy. He reported the natural history of wheezing illnesses after bronchiolitis. A major contribution was the establishment, together with McNicol, of a cohort study of asthma in 7-y-old children (17). This was initially designed to define the features of wheezing illnesses in 60,000 second-grade children in Melbourne, Australia. He showed a pattern of illness that indicated that most 
was due to asthma leading to a marked reduction in the inappropriate use of antibiotics for wheezing bronchitis in children. Subsequently, the patterns of wheezing illnesses in young people have been more refined, but these studies provided the first new approach to understanding this complex problem. This cohort has subsequently been followed up and now, in the 21st century, is having its $42-y$ assessment. As in the United Kingdom, there was also an active interest in lung function in infants and children in Australia, with Eric Burnard reporting important information in neonatal pulmonology with his studies on infant lung physiology, ventilatory response to challenges, and chest wall mechanics (18). David HendersonSmart subsequently continued these important studies in Sydney. In Melbourne, Peter Phelan, who trained with Howard Williams, began making his own special contribution to documenting lung function in children (19).

\section{THE 1970s-1980s: THE NEXT GENERATION}

During the 1970s, The Hospital for Sick Children in London became a hotbed for producing a whole generation of pediatric pulmonologists stimulated by Archie Norman and David Hull. This group included Tony Milner, John Price, Peter Weller, David Heath, and Jeremy Cogswell — some of the first British pediatricians who made a full-time career of pulmonology. It is interesting how often the same personalities appeared in published reports from different institutions and different topics. Milner alone and in collaboration with Cogswell, Lenney, Hiller, and others was producing a whole string of papers on techniques for measuring lung function in infants and young children and what were then original studies of the efficacy of bronchodilators in wheezy infants and toddlers (20-23). John Warner, who was to play such an important role in pediatric pulmonology, showed early on that our specialty not only related to chronic lung diseases such as adenoviral-induced lung damage (24) but also overlapped with pediatric allergy and immunology (25). Always there, stimulating whole generations of others to be interested in the epidemiology and management of pediatric lung diseases, was Hamish Simpson. At the same time, Simon Godfrey and his group at the (now Royal) Brompton Hospital in London were very active in studying the best ways to assess and treat asthma, studies related to exercise-induced asthma and studies of exercise physiology in healthy and sick children (26-34). From the Brompton group emerged a number of very successful pediatric pulmonologists, and without any intention of belittling the contribution of the others, Michael Silverman and Sandra Anderson deserve special mention. Michael went on to become one of the leaders of pediatric pulmonology and professor of pediatrics in Leicester with a remarkable talent for sorting out the wood from the trees and bringing common sense and refined judgment to bear on pulmonary issues. Sandra Anderson joined the group as a laboratory technician and went on to obtain her doctoral degree for research on exercise physiology in children. After a very successful period in the United Kingdom, she returned to her native Australia to work with Ann Woolcock and became, literally, the worldwide authority of exercise-induced asthma research.
After transplanting from the Brompton to the Hammersmith Hospital, Godfrey's group became very involved in the investigation of lung function in infancy and the effect of premature birth and its management on subsequent lung function (35-38). At that time, a young nurse with a bachelor of science degree in nursing and a desire to become a district midwife was persuaded by a lot of arm twisting to join the group. She was, of course, Janet Stocks, who went on the obtain her doctoral degree and become the undisputed "Queen" of infant lung function testing, holding court in the Institute of Child Health at the Great Ormond Street complex. During the 1980s, the same pediatric pulmonologists with a few new recruits were active in the field of lung function testing, especially in infancy, but now with more serious attention to the elucidation of clinical problems $(39,40)$. Several important epidemiologic studies were undertaken to investigate the nature and the prognosis of wheezing in infancy, notably by Mok and Simpson $(41,42)$, and an outstanding study, which is just as valid today, 20 y later, was undertaken by Pullan and Hey (43). In a beautifully designed and executed prospective study, they showed that respiratory syncytial viral bronchiolitis in infancy was associated with transient wheezing over the early years but not with overt asthma in late childhood. The group also began to influence thinking about pulmonary problems in children at a national level and together with some eminent contributors from abroad, John Warner and Michael Silverman, organized the first meeting to establish guidelines for the management of asthma in children (44).

The new generation within continental Europe also began making advances, especially in various aspects of pediatric pulmonary function. Jan Bjure from Sweden was investigating various aspects of exercise physiology and lung function in children and, more recently, in the investigation of cerebral blood flow. Kjell Aas and Svein Oseid in Norway were documenting allergic aspects of childhood asthma (45), while in the Netherlands, Karel Kerrebijn was setting up epidemiologic studies of childhood asthma that produced much important data (46) and are still doing so today. In France, Claude Gaultier has been one of the pioneers in pediatric lung physiology. She has worked with a variety of topics, including describing function in premature infants (47) and their subsequent changes with growth (48), as well as studies of the control of breathing. Roberto Ronchetti in Italy was developing the use of isotopic inert gases to investigate lung function in young children alone and in collaboration with the group in Hammersmith $(35,49)$. During the 1980 s, a number of new pediatric pulmonologists began making contributions in Europe. Max Zach from Austria, whose early study of the relationship between recurrent croup, allergy, and bronchial reactivity (50), was followed by many more clinical and physiologic studies, in addition to which Zach was to play such an important role in the development of the specialty in Europe. In Italy, Attilio Boner established a residential home for children with asthma high in the Alps, where he and his colleagues have undertaken interesting studies of the effect of environment on childhood asthma (51). Francois Marchal from France was beginning a series of important fundamental studies of lung function in children with special emphasis on the use of forced oscillation (52). In the 
Netherlands, Jorrit Gerritsen, the present head of the Pediatric Assembly of the European Respiratory Society, was continuing the tradition of epidemiologic studies of childhood asthma (53).

In Australia, a similar situation was developing with a new generation emerging to expand knowledge in clinical and physiologic aspects of pediatric pulmonology. A number of these pediatricians also traveled abroad to expand their interests and returned to Australia to become driving forces in advancing the specialty. These included Phelan, who went to Boston to work with Jere Mead and colleagues, and Lou Landau, who trained initially with Phelan and then went for a period to Montreal, where he worked with Peter Macklem and Pierre Beaudry and began a long-term collaboration with Lynn Taussig. After returning to Australia, these investigators and their colleagues published a number of important studies that included an evaluation of tests such as oscillation and multiplebreath nitrogen washout for measuring small airway function in children (54), a continuation of the asthma cohort follow-up analysis with James Martin $(55,56)$ as well as numerous studies on the management of asthma and cystic fibrosis with particular focus on treatment and prognosis $(57,58)$. Studies have been continued by Tony Olinsky, Colin Robertson, and Phil Robinson. At the same time in Sydney, the remarkable adult pulmonologist Ann Woolcock, who passed away recently, began to study lung function in children. Her epidemiologic studies with Craig Mellis and Jenny Peat have provided valuable information on the patterns of bronchial reactivity in childhood and further contributed to understanding the evolution of wheezing illnesses through childhood into adult life (59). Others from the group in Sydney included Peter Van Asperen, John Morton, Penny Field, Richard Henry, and Gus Cooper. In New Zealand, Malcolm Sears, another adult pulmonologist, began to study various aspects of the clinical manifestations and epidemiology of childhood asthma (60) and has continued to contribute up to the present time after moving to Canada.

In 1977, Simon Godfrey moved again, this time not just across Hyde Park but from London to take up the chair of pediatrics at the Hadassah University Hospital in Jerusalem. Not only was he able to gather together a local group of budding pediatric pulmonologists, but he also was able to play host to a number of outstanding visitors, among whom were Lou Landau and Lynn Taussig. During a very "mini" sabbatical period of study leave in Jerusalem (and many beers), the rapid thoracic compression technique was developed for the measurement of forced expiratory flows in infants (61). Caroline Beardsmore also spent some time in Jerusalem and made important contributions, which included the development of computer techniques that made it possible to measure airway resistance continuously during tidal breathing in infants (62). Others were also on the move, Lou Landau moved across the continent from Melbourne to Perth and established a major center for pediatric pulmonology. Peter Sly and Peter Le Souef set up in Perth and made important contributions to our understanding of pediatric pulmonary physiology.

It was during the early 1970s that pediatric pulmonary "politics" began to emerge in the United Kingdom. Pediatri- cians who were interested in lung diseases began to arrange an informal society that was named the British Pediatric Respiratory Group and that met chiefly at the annual general meeting of the British Pediatric Association (BPA). This was a very useful and friendly setting at which members were able to pick each other's brains over technology and clinical matters. At first, the group was regarded somewhat with distaste by the BPA members, who were against subspecialty groups that they thought would draw people away from the general pediatric meetings. However, as time went by, the various subspecialty groups' meetings became an established part of the annual BPA meeting. In the late 1980s, the Australian Pediatric Respiratory Group was established. This collaboration between all pediatric pulmonologists in Australia and New Zealand has continued and with input from pediatric pulmonologists in all Australian states and New Zealand have produced important guidelines for understanding and treatment of childhood lung diseases.

During the 1980s, pediatric pulmonology really began to get organized in Europe. Until that time and in fairly characteristic fashion, pulmonology in Europe was represented by several societies. There were two for pulmonology in general-the Societas Europea Pneumologia, which had no interest in pediatrics, and the Societas Europea Physiologiae Clinicae Respiratoriae, which did have a pediatric working group. In addition, there was the independent European Pediatric Respiratory Society (EPRS) as well as pediatric allergy and cystic fibrosis associations and East European pediatric respiratory group (63). Ultimately, a "marriage" was arranged between the Societas Europea Pneumologia and the Societas Europea Physiologiae Clinicae Respiratoriae, the offspring of which was the creation of the European Respiratory Society (ERS). Archie Norman from United Kingdom was one of the early pioneers. John O. Warner and John F. Price were secretary and treasurer in this society. The EPRS continued to run meetings in different parts of Europe, but by 1990, the ERS had also developed its own Pediatric Assembly, and in January 1993, the eighth meeting of the EPRS was organized in Oslo by Kai-Håkon Carlsen as a joint meeting with the Pediatric Assembly of the ERS. At this meeting, in which there were 650 participants, common sense finally prevailed and it was decided that the EPRS should cease as a society and join with the Pediatric Assembly of the European Respiratory Society. This was effected at the last meeting of the EPRS as an independent society in Rotterdam in 1995.

\section{THE 1990s-2000+: CONSOLIDATION}

During the past $12 \mathrm{y}$, pediatric pulmonology in the United Kingdom finally reached maturity and even attained formal recognition as a subspecialty of pediatrics. After much debate and heart searching, the good old BPA finally emerged from infancy and childhood as the mature and fully fledged Royal College of Paediatrics and Child Health. Along with this change, the very informal British Pediatric Respiratory Group became the somewhat more formal British Pediatric Respiratory Society attached to the Royal College, and even more recently, a syllabus for the training of pediatric pulmonologists 
has been established with formal certification on satisfactory completion of the training. Much of this change has been brought about through the hard work of John Price, Michael Silverman, John Warner, and Andy Bush, among others. The U.K. training program also includes training for a pediatrician who has special interest in respiratory medicine and is intended to run a specialist service within a district general hospital rather than a teaching hospital. In the research field, both Janet Stocks and Caroline Beardsmore have been busily applying infant lung function testing to the elucidation of clinical problems $(64,65)$, while Andy Bush and other clinicians have worked hard on developing novel approaches to diagnosis and treatment of lung diseases in childhood (66-68). The Jerusalem group continued to research pediatric pulmonary problems and, in particular, undertook studies into the nature of bronchial hyperreactivity in childhood lung diseases and developed the " $\mathrm{PC}_{\text {wheeze }}$ " technique for measuring bronchial reactivity in preschool children (69-72).

The Perth group has been very active in developing and applying new techniques for measuring lung function in infants and very young children, including the application of forced oscillations to measure impedance (73). Le Souef and his colleagues have further refined the forced expiratory rapid thoracic compression technique with measurements from raised lung volumes (74), and he has also contributed to knowledge in aerosol mechanics and treatment as well as the genetic basis of lung diseases. In association with Patrick Holt, they continue to contribute to the understanding of the immunologic and physiologic evolution of asthma in early childhood. In Melbourne, the studies in clinical aspects of lung disease have been continued by Tony Olinsky and in the epidemiology of childhood asthma by Colin Robertson. Stephen Stick began working with the Perth group and subsequently developed a program that measured the transmission of pressures in the rapid thoracic compression technique and reported studies of ventilatory control, including better understanding of sleep physiology in childhood. In New Zealand, Innes Asher and Pattemore and their colleagues undertook international comparisons of clinical and physiologic aspects of childhood asthma (75), and Asher has taken on the role of Australasian coordinator of the International Study of Asthma and Allergy in Children Studies. In Europe, the group of academic pediatric pulmonologists continued to expand with, among others, the Danish investigators Hans Bisgaard, working on asthma therapy in children, especially in relation to inhaled corticosteroids (76), and Soren Pedersen and Agertoft and their colleagues working chiefly on the side effects of treatment (77). Johannes de Jongste from the Netherlands was working on measuring airway responsiveness (78) and later on exhaled nitric oxide in children, while Kai-Hakon Carlsen of Norway was undertaking a number of studies, including bronchial provocation in young children and the efficacy of inhaled adrenaline (epinephrine) in bronchiolitis (79). Last but by no means least of this group was Erica von Mutius from Germany, whose studies of the differences in asthma incidence in children between the former East and West Germany started the whole concept of the "dirty environment" hypothesis about the prevention of asthma $(80,81)$.
With the winding up of the EPRS in 1993 and its incorporation into the ERS as its Pediatric Assembly, Max Zach was appointed as the first head of the assembly and later went on to become president of the ERS itself. Zach was succeeded by John Warner as head and then from 1997 by Kai-Håkon Carlsen. At the present, Jorrit Gerritsen from Groningen in the Netherlands is the head of the Pediatric Assembly, which is presently the second largest assembly of the ERS. Within the Pediatric Assembly are seven groups that represent all aspects of pediatric pulmonology and neonatology. In addition, specific problems related to pediatric pulmonology may be addressed by ad hoc task forces that are often initiated by the scientific groups. Presently, the Pediatric Assembly has two active task forces. One is the joint task force of ERS and American Thoracic Society on infant lung function tests, headed by Janet Stocks. Historians should note that this important and very fruitful idea was originated by Michael Silverman, Bob Castile, and a few friends in the bar of a hotel in Cincinnati. The second task force, headed by Jacques de Blic, concerns pediatric bronchoalveolar lavage.

Early on, the Pediatric Assembly formed its Long-Range Planning Committee (LRPC), which was initially headed by John Price and now by Felix Sennhauser. With the approval of the executive committee of ERS, the LRPC of the Pediatric Assembly arranged joint meetings with other societies, including the Pediatric Week (Rotterdam 1994), the European Society for Pediatric Allergy and Immunology held in Odense (1996), and again at a special meeting organized by Elif Dagli from Istanbul (Berlin 1999). During the past few years, the European Society for Pediatric Allergy and Immunology has become the Pediatric Section of European Academy of Asthma and Clinical Immunology, and a joint meeting of the Pediatric Assembly, the ERS, and the Pediatric Section of European Academy of Asthma and Clinical Immunology took place in Valencia in Spain in November 2002. The LRPC has also been active in the development of rules for specialization throughout Europe. Max Zach and Attilio Boner have represented LRPC and the Pediatric Assembly and reached agreement within Confederation of European Specialty Pediatrics for a European subspecialty of pediatric respiratory medicine. The European School of Respiratory Medicine was created in 1992 and was responsible for postgraduate courses at the annual congresses of the ERS. It has now developed into the European Respiratory Society School and is organizing postgraduate courses at the annual congress, ERS School Courses on different locations in Europe, and has its own learning resources on the web. Kai-Håkon Carlsen from Oslo is the present head of the ERS school.

\section{WHERE ARE WE NOW?}

Despite some early anxiety that pediatric pulmonology might get swallowed up by the neonatologists and allergists or simply become the realm of the family practitioner or pediatrician (63), this is clearly not the case and the specialty seems to be thriving if one looks at the membership of the professional societies and the constant stream of high-quality publications. Perhaps it was the pediatric fiberoptic bronchoscope 
more than anything else that spurred on the specialty because the pediatric pulmonologist has become the undisputed master of this investigative technique and the clinical information that it elucidates. Lung function testing, especially of infants, has also contributed to a much more evidence-based approach to pediatric respiratory problems as has the intelligent use of computed tomography. Cohort studies are clearly elucidating the perinatal and childhood origins of adult lung disease. The neonatologists and intensivists have gone their own way, albeit with very healthy cooperation, in the management of specific problems. It now looks as though pediatric pulmonologists are here to stay and are recognized by the pediatric profession as the correct address to which to refer children with all but the most straightforward respiratory problems.

Acknowledgments. The authors acknowledge the American Pediatric Society and its council for stimulating and supporting the activities of the Workgroup on History, chaired by Drs. Laurence Finburg and E. Richard Stiehn, which resulted in this manuscript.

\section{REFERENCES}

1. Bray GW 1930 The asthmatic child. Arch Dis Child 5:237-258

2. Asherson N 1940 The importance of bronchoscopy in the recognition of non-opaque foreign body in infants and children. Arch Dis Child 15:121-128

3. Holzel A, Wolman B 1950 The prognosis of pneumonia in infancy and childhood. Arch Dis Child 25:282-285

4. Cross KW 1949 The respiratory rate and ventilation in the newborn baby. J Physiol 109:459-474

5. Cross KW, Oppe TE 1952 The respiratory rate and volume in the premature infant J Physiol 116:168-174

6. Cross KW, Warner P 1951 The effect of inhalation of high and low oxygen concentrations on the respiration of the newborn infant. J Physiol 114:283-295

7. Campbell K 1951 Intensive oxygen therapy as a possible cause of retrolental fibroplasia. A clinical approach. Med J Aust 2:48-50

8. Strang LB 1959 The ventilatory capacity of normal children. Thorax 14:305-310

9. Cross KW, Klaus M, Tooley WH, Weisser K 1960 The response of the new-born baby to inflation of the lungs. J Physiol 151:551-565

10. Strang LB, Knox EG 1960 Choline theophyllinate in children with asthma. A controlled trial. Lancet 1:260-262

11. Jones RS, Buston MH, Wharton MJ 1962 The effect of exercise on ventilatory function in the child with asthma. Br J Dis Chest 56:78-86

12. Floyer Sir J 1698 A Treatise of the Asthma. Wilkins and Innis, London, UK

13. Jones RS 1966 Assessment of respiratory function in the asthmatic child. BMJ 2:972-975

14. Jones RS, Wharton MJ, Buston MH 1963 The place of physical exercise and bronchodilator drugs in the assessment of the asthmatic child. Arch Dis Child 38:539-545

15. Zapletal A, Motoyama EK, Woestijne Van De KP, Hunt VR, Bouhuys A 1969 Maximum expiratory flow-volume curves and airway conductance in children and adolescents. J Appl Physiol 26:308-316

16. Williams H, Campbell P 1960 Generalised bronchiectasis associated with deficiency of cartilage in the bronchial tree. Arch Dis Child 35:182-191

17. Williams H, McNicol KN 1969 Prevalence, natural history and relationship of wheezy bronchitis and asthma in children. An epidemiological study. BMJ 4:321-325

18. Burnard ED, Grattan-Smith P, Picton-Warlow CG, Grauaug A 1965 Pulmonary insufficiency in prematurity. Aust Paediatr J 1:12-38

19. Phelan PD, Williams HE 1969 Ventilatory studies in healthy infants. Pediatr Res 3:425-432

20. Lenney W, Milner AD 1978 At what age do bronchodilator drugs work? Arch Dis Child 53:532-535

21. Milner AD 1970 The respiratory jacket. A new method for measuring respiration. Lancet 2:80-81

22. Milner AD, Hull D, Hatch DJ, Cogswell JJ 1972 A new method for measuring static compliance in infants and young children. Clin Sci 43:689-694

23. Rutter N, Milner AD, Hiller EJ 1975 Effect of bronchodilators on respiratory resistance in infants and young children with bronchiolitis and wheezy bronchitis. Arch Dis Child 50:719-722

24. Warner JO, Marshall WC 1976 Crippling lung disease after measles and adenovirus infection. Br J Dis Chest 70:89-94

25. Warner JO 1976 Significance of late reactions after bronchial challenge with house dust mite. Arch Dis Child 51:905-911

26. Anderson SD, Connolly NM, Godfrey S 1971 Comparison of bronchoconstriction induced by cycling and running. Thorax 26:396-401
27. Anderson SD, Silverman M, Konig P, Godfrey S 1975 Exercise-induced asthma. Br J Dis Chest 69:1-39

28. Connolly N, Godfrey S 1970 Assessment of the child with asthma. J Asthma Res 8:31-36

29. Godfrey S 1970 Physiological response to exercise in children with lung or heart disease. Arch Dis Child 45:534-538

30. Godfrey S, Balfour-Lynn L, Tooley M 1978 A three- to five-year follow-up of the use of the aerosol steroid, beclomethasone dipropionate, in childhood asthma. J Allergy Clin Immunol 62:335-339

31. Godfrey S, Davies CT, Wozniak E, Barnes CA 1971 Cardio-respiratory response to exercise in normal children. Clin Sci 40:419-431

32. Godfrey S, Kamburoff PL, Nairn JR 1970 Spirometry, lung volumes and airway resistance in normal children aged 5 to 18 years. Br J Dis Chest 64:15-24

33. Godfrey S, Mearns M 1971 Pulmonary function and response to exercise in cystic fibrosis. Arch Dis Child 46:144-151

34. Silverman M, Connolly NM, Balfour-Lynn L, Godfrey S 1972 Long-term trial of disodium cromoglycate and isoprenaline in children with asthma. BMJ 3:378-381

35. Ronchetti R, Stocks J, Freedman N, Glass H, Godfrey S 1975 Clinical application of regional lung function studies in infants and small children using 13N. Arch Dis Child 50:595-603

36. Stocks J, Godfrey S 1976 The role of artificial ventilation, oxygen, and CPAP in the pathogenesis of lung damage in neonates: assessment by serial measurements of lung function. Pediatrics 57:352-362

37. Stocks J, Godfrey S 1977 Specific airway conductance in relation to postconceptional age during infancy. J Appl Physiol 43:144-154

38. Stocks J, Levy NM, Godfrey S 1977 A new apparatus for the accurate measurement of airway resistance in infancy. J Appl Physiol 43:155-159

39. Clements BS, Warner JO 1987 Pulmonary sequestration and related congenital bronchopulmonary-vascular malformations: nomenclature and classification based on anatomical and embryological considerations. Thorax 42:401-408

40. McKenzie SA, Allison DJ, Singh MP, Godfrey S 1980 Unilateral hyperlucent lung: the case for investigation. Thorax 35:745-750

41. Mok JYQ, Simpson H 1982 Outcome of acute lower respiratory tract infection in infants: preliminary report of seven-year follow-up study. Br Med J 285:333-337

42. Mok JYQ, Simpson H 1984 Symptoms, atopy and bronchial reactivity after lower respiratory infection in infancy. Arch Dis Child 59:299-305

43. Pullan CR, Hey EN 1982 Wheezing, asthma and pulmonary dysfunction 10 years after infection with respiratory syncytial virus in infancy. Br Med J 284:1665-1669

44. Warner JO, Gotz M, Landau LI, Levison H, Milner AD, Pedersen S, Silverman M 1989 Management of asthma: a consensus statement. Arch Dis Child 64:1065-1079

45. Havnen J, Amlie PA, Hvatum M, Oseid S, Veggan T, Aas K 1973 IgE concentrations in allergic asthma in children. Arch Dis Child 48:850-855

46. Van Essen-Zandvliet EE, Hughes MD, Waalkens HJ, Duiverman EJ, Pocock SJ, Kerrebijn KF, the Dutch Chronic Non-specific Lung Disease Study Group 1992 Effects of 22 months of treatment with inhaled corticosteroids and/or beta-2-agonists on lung function, airway responsiveness, and symptoms in children with asthma. Am Rev Respir Dis 146:547-554

47. Gaultier C, Boule M, Allaire Y, Clement A, Girard F 1979 Growth of lung volumes during the first three years of life. Bull Eur Physiopathol Respir 15:1103-1116

48. Lebourges F, Moriette G, Boule M, Delaperche MF, Relier JP, Gaultier C 1990 Pulmonary function in infancy and in childhood following mechanical ventilation in the neonatal period. Pediatr Pulmonol 9:34-40

49. Ronchetti R, Geubelle F, Chantraine JM, Senterre J 1971 Studio del rapporto ventilazione/ perfusione nel neonato mediante lo Xe133. Minerva Pediatr 23:1476-1485

50. Zach MS, Schnall RP, Landau LI 1980 Upper and lower airway hyperreactivity in recurrent croup. Am Rev Respir Dis 121:979-983

51. Boner AL 1985 Pulmonary function and bronchial hyperreactivity in asthmatic children with house dust mite allergy during prolonged stay in the Italian Alps (Misurina, $1756 \mathrm{~m}$ ). Ann Allergy 54:42-45

52. Marchal F, Peslin R, Duvivier C, Gallina C, Crance JP 1988 Mechanics of the ventilatory system in sedated infants: forced oscillations versus single-breath method. Pediatr Pulmonol 5:19-26

53. Gerritsen J, Koeter GH, Postma DS, Schouten JP, Knol K 1989 Prognosis of asthma from childhood to adulthood. Am Rev Respir Dis 140:1325-1330

54. Landau LI, Mellis CM, Phelan PD, Bristowe B, McLennan L 1979 "Small airways disease" in children: no test is best. Thorax 34:217-223

55. Martin AJ, Landau LI, Phelan PD 1982 Asthma from childhood at age 21: the patient and his disease. BMJ (Clin Res Ed) 284:380-382

56. Martin AJ, McLennan LA, Landau LI, Phelan PD 1980 The natural history of childhood asthma to adult life. BMJ 280:1391-1482

57. Hudson I, Phelan PD 1987 Are sex, age at diagnosis, or mode of presentation prognostic factors for cystic fibrosis? Pediatr Pulmonol 3:288-297

58. Phelan PD, Allan JL, Landau LI, Barnes GL 1979 Improved survival of patients with cystic fibrosis. Med J Aust 1:261-263

59. Woolcock AJ, Leeder SR, Peat JK, Blackburn CR 1979 The influence of lower respiratory illness in infancy and childhood and subsequent cigarette smoking on lung function in Sydney schoolchildren. Am Rev Respir Dis 120:5-14

60. Sears MR, Burrows B, Flannery EM, Herbison GP, Hewitt CJ, Holdaway MD 1991 Relation between airway responsiveness and serum $\operatorname{IgE}$ in children with asthma and in apparently normal children. N Engl J Med 325:1067-1071

61. Taussig LM, Landau LI, Godfrey S, Arad I 1982 Determinants of forced expiratory flows in newborn infants. J Appl Physiol 53:1220-1227

62. Beardsmore CS, Godfrey S, Shani N, Maayan C, Bar-Yishay E 1986 Airway resistance measurements throughout the respiratory cycle in infants. Respiration 49:81-93

63. Zach MS 1991 Pediatric respiratory medicine in Europe. Pediatr Pulmonol 10:150-156 
64. Beardsmore CS, MacFadyen UM, Johnstone MS, Williams A, Simpson H 1994 Clinical findings and respiratory function in infants following repair of oesophageal atresia and tracheo-oesophageal fistula. Eur Respir J 7:1039-1047

65. Thompson AH, Beardsmore CS, Firmin R, Leanage R, Simpson H 1990 Airway function in infants with vascular rings: preoperative and post operative assessment Arch Dis Child 65:171-174

66. Bush A, Sheppard MN, Warner JO 1992 Chloroquine in idiopathic pulmonary hemosiderosis. Arch Dis Child 67:625-627

67. Payne D, McKenzie SA, Stacey S, Misra D, Haxby E, Bush A 2001 Safety and ethics of bronchoscopy and endobronchial biopsy in difficult asthma. Arch Dis Child $84: 423-426$

68. Phillips GE, Thomas S, Heather S, Bush A 1998 Airway response of children with primary ciliary dyskinesia to exercise and $\beta_{2}$-agonist challenge. Eur Respir J 11:1389-1391

69. Avital A, Bar-Yishay E, Springer C, Godfrey S 1988 Bronchial provocation tests in young children using tracheal auscultation. J Pediatr 112:591-594

70. Avital A, Springer C, Bar-Yishay E, Godfrey S 1995 Adenosine, methacholine, and exercise challenges in children with asthma or paediatric chronic obstructive pulmonary disease. Thorax 50:511-516

71. Noviski N, Cohen L, Springer C, Bar-Yishay E, Avital A, Godfrey S 1991 Bronchia provocation determined by breath sounds compared with lung function. Arch Dis Child 66:952-955

72. Springer C, Godfrey S, Picard E, Uwyyed K, Rotschild M, Hananya S, Noviski N Avital A 2000 Efficacy and safety of methacholine bronchial challenge performed by auscultation in young asthmatic children. Am J Respir Crit Care Med 163:857-860
73. Sly PD, Hayden MJ, Petak F, Hantos Z 1996 Measurement of low-frequency respiratory impedance in infants. Am J Respir Crit Care Med 154:161-166

74. Turner DJ, Stick SM, LeSouef KL, Sly PD, LeSouef PN 1995 A new technique to generate and assess forced expiration from raised lung volume in infants. Am J Respir Crit Care Med 151:1441-1450

75. Pattemore PK, Asher MI, Harrison AC, Mitchell AC, Rea HH, Stewart AW 1990 The interrelationship among bronchial hyperresponsiveness, the diagnosis of asthma, and asthma symptoms. Am Rev Respir Dis 142:549-554

76. Bisgaard H, Gillies J, Groenewald M, Maden C 1999 The effect of inhaled fluticasone propionate in the treatment of young asthmatic children: a dose comparison study. Am J Respir Crit Care Med 160:126-131

77. Wolthers OD, Hansen M, Juul A, Nielsen HK, Pedersen S 1997 Knemometry, urine cortisol excretion, and measures of insulin-like growth factor axis and collagen turnover in children treated with inhaled glucocorticosteroids. Pediatr Res 41:44-50

78. Van Broekhoven P, Hop WCJ, Rasser E, De Jongste JC, Kerrebijn KF 199 Comparison of FEV1 and transcutaneous oxygen tension in the measurement of airway responsiveness to methacholine. Pediatr Pulmonol 11:254-258

79. Lodrup Carlsen KC, Carlsen KH 2000 Inhaled nebulized adrenaline improves lung function in infants with acute bronchiolitis. Respir Med 94:709-714

80. von Mutius E 1998 Air pollution and asthma - fact or artifact? A plea for inclusion of objective measures in environmental epidemiology. Pediatr Pulmonol 25:297-298

81. Weiland SK, von Mutius E, Hirsch T, Duhme H, Fritzsch C, Werner B, Husig A, Stender M, Renz H, Leupold W, Keul U 1999 Prevalence of respiratory and atopic disorders among children in East and West of Germany five years after unification. Eur Respir J 14:862-870 